\title{
PRODUCTION TECHNOLOGIES OF FORMED PREMIXES
}

\begin{abstract}
The article presents theoretical analysis and practical experience of the production of premixes $(P)$ by different technologies of preparation of the filler. Their advantages and disadvantages are stated. The classification of premix fillers is presented and the distribution of biologically active substances in the premix composition, which is made on different fillers, is schematically presented.

The technology of production of a complex filler of premixes (CFP) in the form is theoretically and practically substantiated. Various methods of forming depending on the composition of the complex filler are considered, as well as the technological scheme of their production is presented.

The results of industrial approbation of technologies of forming (granulation, briquetting, rolling, extrusion) of fillers and ready premixes in the production conditions of TG "VBA" "Izvestnyaki" are presented. The physical indicators of the formed complex fillers / premixes were investigated, and on the basis of the analysis of the obtained data it was found that granulation and briquetting can be subjected to CFP consisting of $75 \ldots 50 \%$ wheat bran and $25 \ldots 50 \%$ limestone flour. The pellet is a CFP consisting of $85 \%$ wheat bran and 15\% limestone flour. Optimal technological modes of forming KNP and P in different ways have been established, as a result of which it is possible to obtain particles of $P$, which, upon further mixing with the feed components, ensure a high homogeneity of the finished feed.

The results of the study of microbiological parameters are presented, it is established that the formation of CFP or P reduces the bacterial flora and improves the conditions during their storage.

The proposed technological methods of preparation of CFP can eliminate the stratification and stabilize its composition during transportation and storage.
\end{abstract}

Keywords: premix (P), excipient, complex filler of premixes (CFP), granules, pellets, extrudate, cereals, granulation technology, technological modes, homogeneity, physical properties, microbiological parameters.

\section{Introduction}

The quality of the premixes depends largely on the quality of the raw material that is included in their composition, the physical properties of the filler and the efficiency of the manufacturing process.

In the production of premixes, the filler plays an important role in ensuring their quality, since the uniformity of the distribution of micro components depends on its properties. The main purpose of premix fillers is to separate one particle from another chemically incompatible biologically active additive (BAA) preparation, which helps to preserve the activity of the latter, and to ensure their uniform distribution, both in the premix itself and in the protein-vitamin additive feed (PVA), protein-vitamin-mineral additives (PVMA), feed mixture [14].

In the $70 \ldots 80$-ies of the last century in the production of premixes used classical mono filler (organic or mineral) $[3,5,6]$.

The development of premix production technologies is due not only to technological innovations [7, 8], but also to changes in the properties of BAA preparations [9-11] and the improvement of preparation of premix fillers [1, 2, 12-14]. Substantial changes in the physical properties of BAA preparations (increase in density, bulk mass, etc.) used for the production of premixes have prompted scientists and manufacturers of premixes to search for and introduce into the technology of production of premixes of complex fillers, the physical properties of which best meet the requirements of mixing BAA and ensure the stability of the finished product composition.

In the early 2000 s, premix manufacturers began to use complex fillers, which consist of two or three fillers, which perform the functions of a carrier that maximally retains the BAA and ensures homogeneity of the mixture, and a diluent that improves the physical properties of the mixture and maintains the activity of BAA [15- 17].

The most effective and cost-effective is the use of complex premix filler (CFP), which consists of wheat and limestone flour $(75: 25 ; 50: 50 ; 15: 85)$, whose technology was developed in 2002-2006 by Yegorov B.V., Makarynska A.V., Brazhenko V.E. [18-20]. The use of dry neutral filler diluent, namely limestone flour in the composition of the complex filler, in a certain ratio, affects the redistribution of moisture in the finished complex filler, which allows to obtain a filler with a predetermined value of the mass fraction of moisture in the range from 8 to $10 \%$ without the use of energy . The increase in the mass fraction of wheat bran in the composition of complex fillers more than $75 \%$ leads to a mixture that does not meet the requirements for fillers in terms of the content by mass of moisture in the production of premixes [21, 22].

BioPro and Adisseo Eurasia LLC have developed a pseudocapsulation technology that anticipates the production of premixes containing BAA that are fixed on carrier particles (wheat bran) and covered externally by a 
mineral shell of classic pre-mixes, such as premixes, turtle flour). The pseudocapsule thus obtained has less contact with water and oxygen, is therefore more resistant to oxidation and does not disintegrate, which has a positive effect on the preservation of BAA drugs [23].

The presence of protected forms of vitamin preparations Adisseo, BASF, DSM Nutritional Products, Kaesler Animal Nutrition, Orffa Additives BV, Lonza, MIAVIT, Sunvit, while adhering to the technology of production of premixes with the use of complex fillers guarantees the uniform distribution of all BAA in the composition of premixtures domestic and foreign scientists [24-28]. However, in the further transportation, movement of the premix and its mixing with other components of compound feed there is a pressing question to ensure the stability of the composition and the uniform distribution of the BAA. Technology for the production of premixes in the form of "granules" without the use of heat treatment, proposed by "Nutristar International" S.A. (France) allows to ensure uniform distribution of BAA in the composition of the premix, but such a premix is used to enrich and balance the diets of industrial laying hens and breeding adult poultry only in bulk feed and excludes its use for young animals [29].

To eliminate these shortcomings, we have proposed a technology of mechanical encapsulation, which provides: separate preparation of fillers in the traditional way, by sieving on the puncture sieves PS No. $12(\varnothing 1.2$ $\mathrm{mm}$ ) with subsequent grinding of a large fraction and mixing the pass fractions of PS No. 12 in these ratios; the introduction of $0,1-2,0 \%$ of the enhancer Thixosil ${ }^{\circledR} 38 \mathrm{~A}$ (Aventis); the introduction of 1,5-2,0\% vegetable oil at the stage of formation of the pre-mixture of filler and BAA; selection of the powder fraction at the stage of preparation of fillers through sieve kapron No. 27 and its subsequent deposition at the final stage of production of complex filler [30].

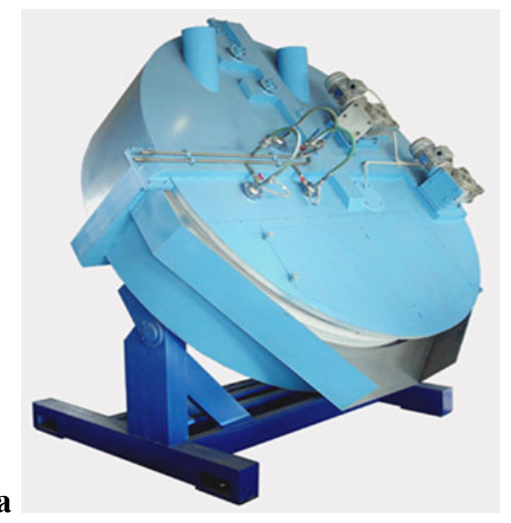

Also, in the production of complex fillers, methods for reducing the cost of ready-mix premixes have been proposed due to the use of trace element-rich diluents (bentonite clays, algae groats) and subsequent conversion of mineral and complex premixes [31-33].

The purpose and objectives of the study

The purpose of the work is to improve the technology of preparation of complex filler, which will ensure efficient distribution of BAA and their stability in the composition of premixes.

To achieve this goal it was necessary to solve the following problems:

- to carry out the analysis of technologies of preparation of fillers;

- improve the technology of preparation of CFP by its formation in various ways;

- to investigate the physical and microbiological quality indicators of CFP and premixes based on them;

- determine the homogeneity of the distribution of microcomponents in the premix;

- to carry out industrial testing of CFP production using different methods of formation and use in the production of premixes and compound feeds.

\section{Materials and equipment}

Objects of study - crumbly and molded CFP, consisting of bran of wheat and limestone flour in a ratio of 75:25; 50:50; 15:85; extruded CFP, consisting of wheat bran and kelp kelp in a ratio of 85:15 [34]; complex premixes based on them [18-20], 0,2 \% Rovimix P-5-2 MCLN blend DSM for broilers.

Formation of CFP / complex premixes was carried out on the basis of ONAFT Department of Combined Feeds and Biofuels Technology and industrial conditions of Izvestnyaky "VBA" (Kamyanets-Podilsk) using technological equipment (Fig. 1), the technical characteristics of which are given in Table 1

Fig. 1 - Technological equipment for producing molded CNC

a - plate granulator "T" $150 \mathrm{M}, \mathrm{b}$ - press granulator OPG-150, c - extruder EZ-150

Table 1 - Technical characteristics of process equipment

\begin{tabular}{|c|c|c|c|c|}
\hline Type of equipment & $\begin{array}{l}\text { Overall dimensions (length, width, } \\
\text { height, diameter, } \mathrm{mm} \text { ) }\end{array}$ & $\begin{array}{c}\text { Engine power, } \\
\mathrm{kW} \\
\end{array}$ & $\begin{array}{c}\text { Productivity, } \\
\mathrm{t} / \mathrm{h}\end{array}$ & $\begin{array}{c}\text { Final } \\
\text { product }\end{array}$ \\
\hline Plate granulator $« \mathrm{~T} » 150 \mathrm{M}$ & $\begin{array}{l}1860 \times 1950 \times 2300 \\
\varnothing \text { plates } 1500 \mathrm{~mm} \\
\end{array}$ & 5,5 & $0,8-1,8$ & You roll \\
\hline \multirow[t]{2}{*}{ Granulator OPG 150} & $\begin{array}{l}800 \times 400 \times 900 \\
\varnothing \text { die } 4,7 \mathrm{~mm} \\
\end{array}$ & \multirow[t]{2}{*}{4,0} & \multirow[t]{2}{*}{$0,1-0,15$} & Granules \\
\hline & $\varnothing \operatorname{die} 19,0 \mathrm{~mm}$ & & & Briquettes \\
\hline Extruder E3-150 & $1700 \times 750 \times 2000$ & 19,0 & 0,15 & Extrudate \\
\hline
\end{tabular}


In the work used standard methods for determining the physical properties of raw materials and finished products $[4,35]$.

Microbiological quality indicators were determined by: total number of mesophilic anaerobic bacteria and optional anaerobic microorganisms per $1 \mathrm{~g}$ of product (MAFAM); the number of molds in $1 \mathrm{~g}$; the presence and titer of bacteria of the group of Escherichia coli (BGEC); the presence of pathogens of the genus Salmonella and Staphylococcus; the presence of obligate anaerobic microorganisms.

The analysis was washed with microorganisms from particles of bran and premixes. To obtain reliable results on the degree of contamination of the samples by microorganisms were prepared ten times dilution of the wash 100 and 1000 times. The total number of microorganisms in $1 \mathrm{~g}$ was determined by sowing $1 \mathrm{~cm} 3$ with a dilution of 1000 times, pathogenic and obligate-anaerobic microorganisms were found from a dilution of 10 times, the titer of BGKP - from a dilution of 10, 100 and 1000 times according to [36-37].

The homogeneity of premixes was evaluated by a complex technique by determining the content of a key component (vitamin B2) by the colorimetric method [38], analyzing the hydrogen extracts of the experimental samples of the premix on the photocolorimeter of the $\mathrm{KFK}$ and $\mathrm{pH}$ meter [18].

\section{Results of the studies and their discussion}

On the basis of analysis and generalization of existing technologies of premix production we have developed a classification of premix fillers, which is presented in Fig. 2.

The vast majority of compound feeds today are made in the form of pellets or compound feed. In connection with what we have, based on the previous development of the technology of production of compound feeds of granulometric composition [39, 40] and the use of thermostable forms of preparations of BAA $[36,41]$, the following hypotheses were put forward:

- obtaining molded fillers and premixes on its basis will allow to produce stable premixes of fixed composition;

production of granulometrically prepared premixes will improve the mixing conditions with other components of compound feed, in particular in the production of compound feed in the form of cereals.
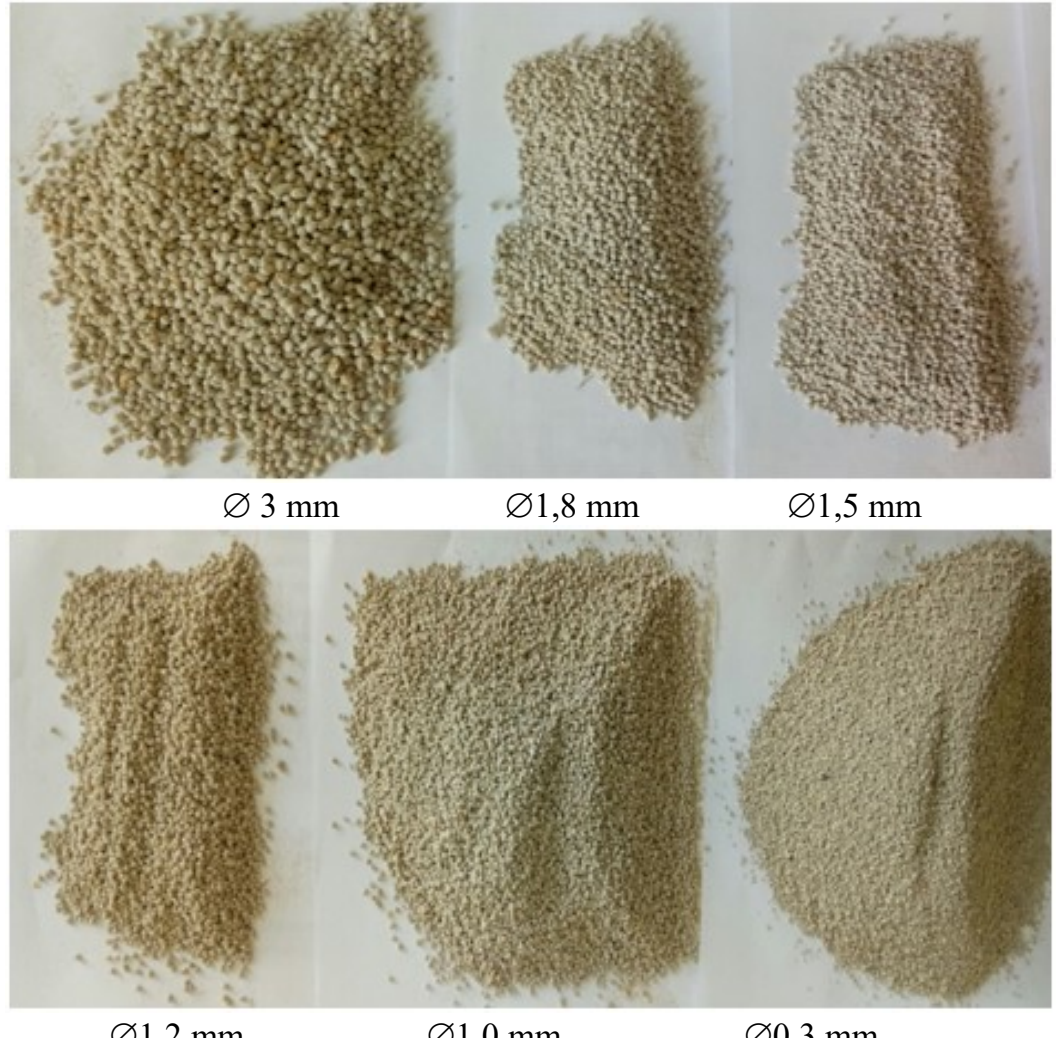

Fig. 3 - CFP pellets obtained by rolling

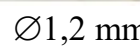
production "Izvestnyaki" (Kamyanets-Podilsk), it was proposed to use the technology of rolling with obtaining spherical granules in the preparation of CPF for mineral premixes (ratio of wheat bran and limestone flour - 15:85) different fractions from 0.3 to $3 \mathrm{~mm}$ (Fig. 3), since the formation of molded particles by the method of classical granulation or extrusion was physically impossible. 


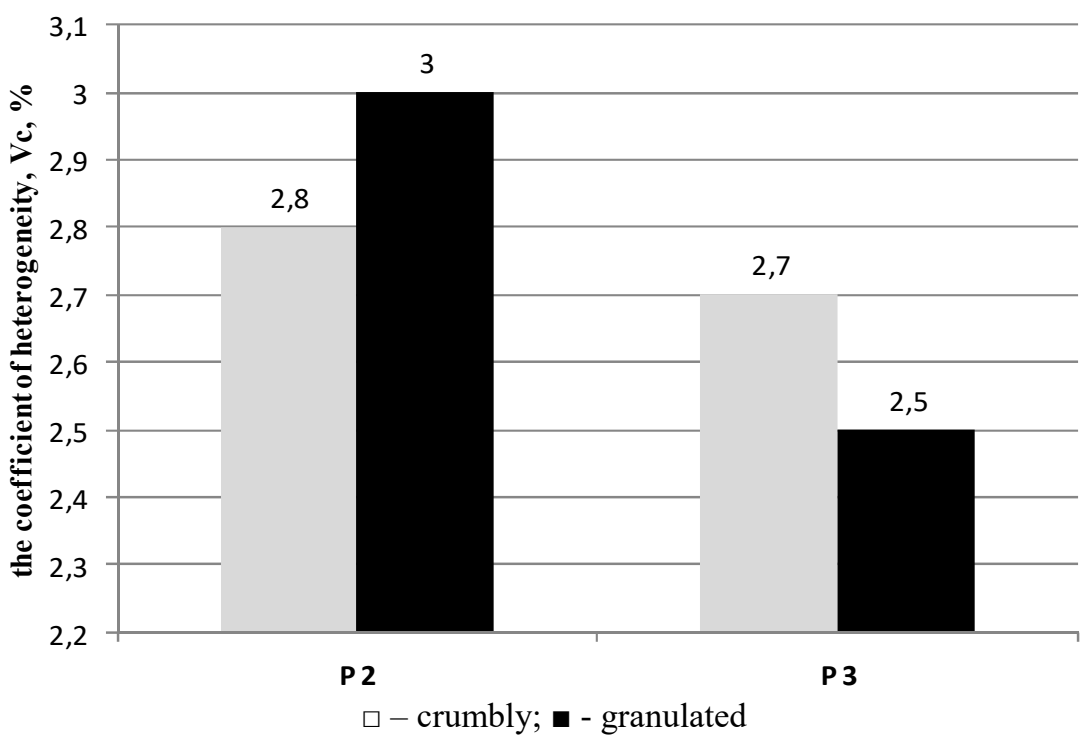

Fig. 4 - Homogeneity of mineral premixes $(P)$ in the content of vitamin $B 2$ :

P1 (based on CFP 75:25), P2 (CFP 50:50), P2 (CFP 15:85), the first value corresponds to wheat bran, the second - to limestone flour

150 revolutions $^{-1}$, use of binders $(2,5 \%$ hydrogen solution of carboxymethylcellulose $(\mathrm{CMC}))$, fractionation of spherical granules by size.

This technology has been tested to produce $1 \%$ of premixes based on CFP. The assessment of the homogeneity of premixes was determined by the content of vitamin B2 in the hydrogen extracts of the test samples. The research results are presented in Figs. 4. The obtained data indicate that the method of curing is advisable to use in the production of mineral premixes on the basis of CFP 3, because it was at the ratio of wheat bran and limestone flour 15:85 was obtained the most homogene-

The technology provided for the production of CFP by dosing and mixing of components, granulation by the method of pelleting at the following technological modes: $\mathrm{d}$ plates $=1,5 \mathrm{~m}$, tilt angle of the plate $55-60$ deg., Without heating the plate, the speed of the plate $n=$ ous mixture (the coefficient of variation was the lowest $2.5 \%$ ). This technology has been patented in 2019 .

In the preparation of CFP for vitamin and complex premixes, it is proposed to use granulation or briquetting technology, with subsequent production of CFP

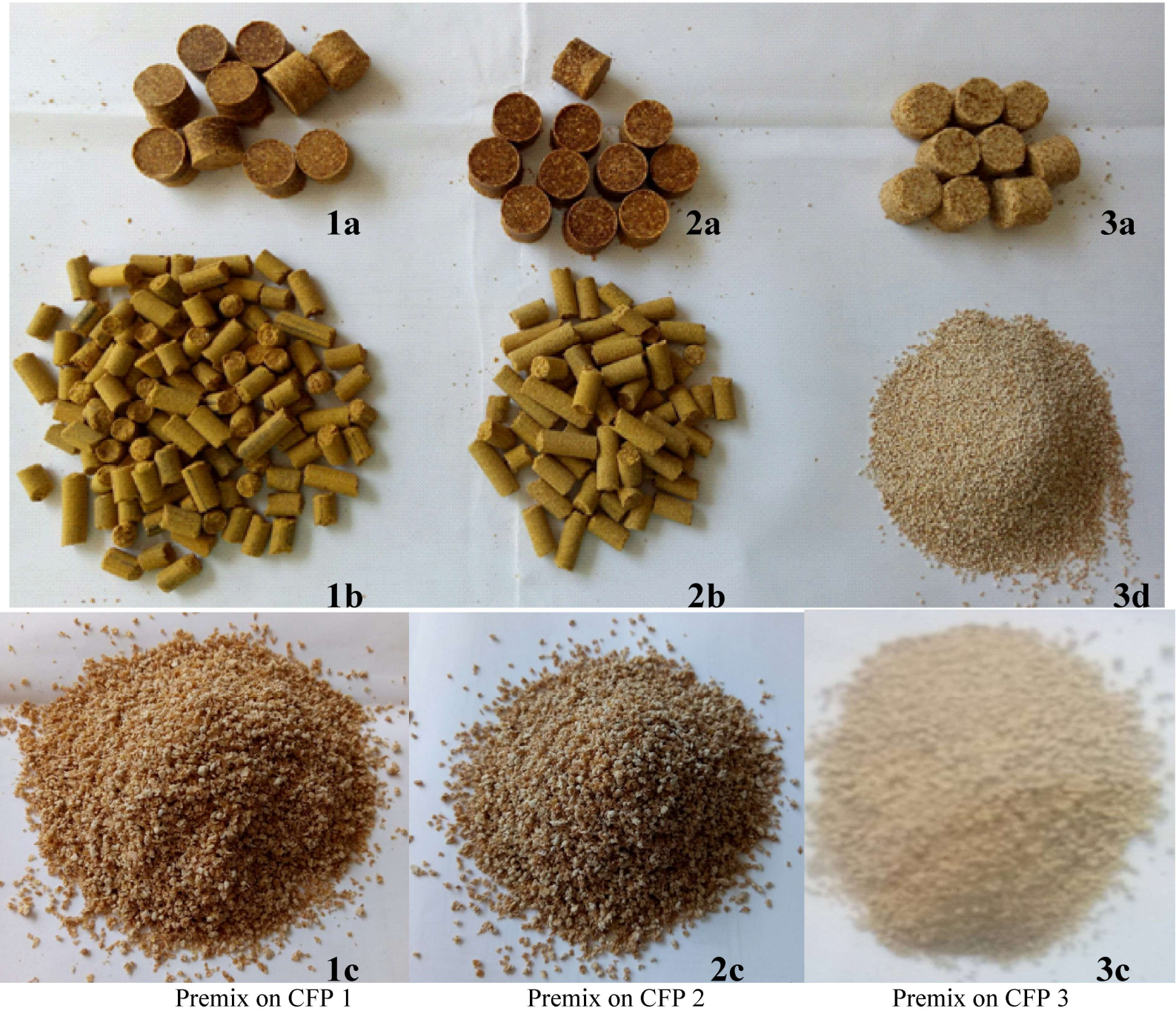

Fig. 5 - Premix obtained by the following methods:

briquetting (a), granulation (b), cereals $(c)$, rolling $(d)$ 


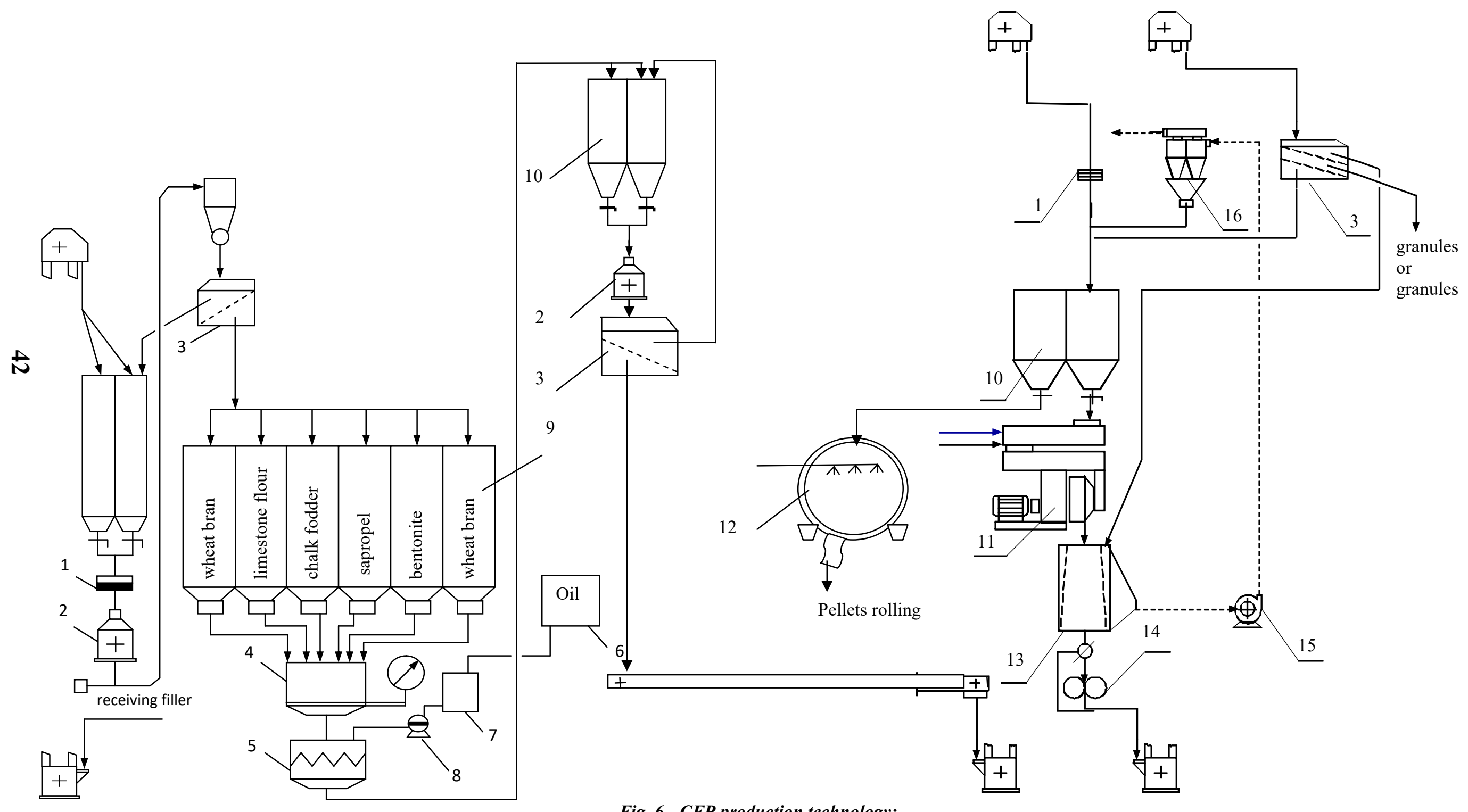

Fig. 6 - CFP production technology:

1 - magnetic separator, 2 - crusher, 3 - screening roller, 4 - weight dispenser, 5 - mixer, 6 - oil container, 7 - filter, 8 - pump dispenser, 9 - over metering bins, 10 - hopper, 11 - press granulator, 12 - plate granulator, 13 - cooling column, 14 - roller shredder, 15 - fan, 16 - filter cyclone 
particles corresponding to the feed grain size.

The technology provides for the production of CFP / or premix on its basis by dosing and mixing the components according to the technological scheme (Fig. 6 ), the subsequent formation in compliance with the respective technological modes:

mass fraction of mois-

granulation briquetting

ture, $\mathrm{W}, \%$

diameter of die, $\varnothing, \mathrm{mm}$

pressure, $\mathrm{P}, \mathrm{M \Pi \textrm {a }}$

matrix heating tempera-

ture, ${ }^{\circ} \mathrm{C}$

temperature of the pel-

lets at the exit of the

press, ${ }^{\circ} \mathrm{C}$

$\mathrm{CMC}$ binder, $\%$

$$
\begin{array}{cc}
4,7 \ldots 12,7 & 19 \ldots 25 \\
1-2 & 1 \\
+90 \ldots 95 & +80 \ldots 85 \\
+70 & +60 \\
2 \ldots 3 & 2 \ldots 3
\end{array}
$$

The obtained granules / briquettes of CFP / premix (Fig. 5) after cooling to a temperature not exceeding the ambient temperature of $10^{\circ} \mathrm{C}$, were crushed in a roller shredder, and then sifted on sieves punching PS No. 20-30 with a hole diameter of $2 \ldots 3 \mathrm{~mm}$ and PS No. 10 with a hole diameter of $1 \mathrm{~mm}$, in order to obtain a fraction corresponding to the size of the compound feed.

Such technological techniques in the preparation of CFP and premixes themselves allow to obtain agglomerates of the product with the given sizes, to eliminate delamination and to stabilize the composition of CFP / premix during transportation and storage, which also further provides optimal conditions for its mixing with preparations of BAA / compound feed and preparation products.

Physical properties were investigated for the obtained samples of bulk and molded CFP and premixes. The results are presented in table. 2 .

Analyzing these tables. 2 it can be concluded that the physical properties of CFP 1 and CFP 2 most closely approximate the physical properties of the finished compound feed, which, when mixed, will ensure a high uniformity. The best physical properties are characterized by CFP 3 in the form of pellets, since it has the smallest natural slope angles for fractions with a particle size of $1,0 \ldots 1,1 \mathrm{~mm}$.

\begin{tabular}{|c|c|c|c|c|c|}
\hline Components & $\begin{array}{l}\text { Moisture } \\
\text { content, } \%\end{array}$ & $\begin{array}{l}\text { The average parti- } \\
\text { cle size, } \mathrm{mm}\end{array}$ & $\begin{array}{l}\text { Angle of native } \\
\text { slope, deg. }\end{array}$ & $\begin{array}{c}\text { Bulk mass, } \\
\mathrm{kg} / \mathrm{m} 3\end{array}$ & $\begin{array}{l}\text { Density, } \\
\mathrm{kg} / \mathrm{cm} 3\end{array}$ \\
\hline \multicolumn{6}{|c|}{ Fillers } \\
\hline Wheat bran & 12,4 & 0,73 & 48 & 390 & 1,20 \\
\hline Limestone flour & 0,9 & 0,43 & 41 & 1250 & 1,71 \\
\hline CFP $1(75 / 25)$ & 8,5 & 0,52 & 47 & 480 & 1,30 \\
\hline CFP $2(50 / 50)$ & 6,1 & 0,50 & 46 & 620 & 1,52 \\
\hline CFP $3(15 / 85)$ & 2,5 & 0,45 & 43 & 1120 & 1,65 \\
\hline \multicolumn{6}{|c|}{ Scatter premixes } \\
\hline Premix 1(WB75/LF25) & 8,3 & 0,50 & 46 & 520 & - \\
\hline Premix 2(WB50/LF50) & 6,2 & 0,47 & 45 & 635 & - \\
\hline Premix 3(WB15/LF85) & 2,3 & 0,42 & 42 & 1150 & - \\
\hline \multicolumn{6}{|c|}{ Premixes granulated $(\varnothing 7.7 \mathrm{~mm})$, crushed (sieve passage fraction $\varnothing 1.2 \mathrm{~mm}$ ) } \\
\hline Premix 1 (pellets) & 7,6 & 0,55 & 46 & 680 & 1,20 \\
\hline Premix 2 (pellets) & 7,2 & 0,50 & 44 & 760 & 1,50 \\
\hline \multicolumn{6}{|c|}{ Premixes briquetted $(\varnothing 19 \mathrm{~mm})$, crushed (sieve passage fraction $\varnothing 1,2 \mathrm{~mm})$} \\
\hline & & $\mathrm{d} / \mathrm{l}, \mathrm{mm}$ & & & \\
\hline Premix 1 & 7,9 & 0,53 & 46 & 675 & 1,21 \\
\hline Premix 2 & 7,5 & 0,49 & 44 & 750 & 1,48 \\
\hline Premix 3 & 7,0 & 0,46 & 43 & 1100 & 1,68 \\
\hline \multicolumn{6}{|c|}{ Premix 3 (pellets rolling) } \\
\hline Premix 3 (WB15/LF85) & 6,8 & 0,4 & 45 & 1450 & 1,71 \\
\hline & 6,8 & 1,0 & 42 & 1360 & 1,60 \\
\hline & 6,8 & 1,1 & 40 & 1220 & 1,45 \\
\hline \multicolumn{6}{|c|}{ Mixed feed MF1-5 + premix granulated crushed } \\
\hline $\mathrm{MF}+\mathrm{P} 1$ & 12,0 & 0,55 & 43 & 550 & 1,35 \\
\hline $\mathrm{MF}+\mathrm{P} 2$ & 12,0 & 0,55 & 43 & 560 & 1,41 \\
\hline $\mathrm{MF}+\mathrm{P} 3$ & 11,9 & 0,56 & 43 & 575 & 1,48 \\
\hline
\end{tabular}

Of particular importance during the industrial testing of technology is the stability of finished products during storage, so at the final stage of industrial testing

Table 2 - Physical properties of CFP and premixes based on them 
Table 3 - The composition of the microflora of premixes before and after storage for 40 days

\begin{tabular}{|c|c|c|c|c|c|c|c|}
\hline \multirow{2}{*}{ Sample } & \multicolumn{2}{|c|}{ Bacteria, CFU / g incl. } & \multirow[b]{2}{*}{ Decaying } & \multirow{2}{*}{$\begin{array}{c}\text { TBGEC } \\
\text { caption, } \\
\mathrm{g}\end{array}$} & \multirow[b]{2}{*}{ Salmonella } & \multirow[b]{2}{*}{ S.Aureus } & \multirow[b]{2}{*}{ Proteus } \\
\hline & $\begin{array}{l}\text { the total } \\
\text { number of }\end{array}$ & E.herbicola & & & & & \\
\hline $\begin{array}{l}\text { Wheat bran } \\
\text { to storage }\end{array}$ & 2500 & 650 & \multirow[t]{2}{*}{ not found } & 0.1 & \multirow[t]{2}{*}{ not found } & \multirow{2}{*}{$\begin{array}{l}\text { not } \\
\text { found }\end{array}$} & \multirow{2}{*}{$\begin{array}{l}\text { not } \\
\text { found }\end{array}$} \\
\hline after storage & 3200 & 680 & & $>0.1$ & & & \\
\hline $\begin{array}{r}\text { Limestone flour } \\
\text { to storage }\end{array}$ & 700 & \multirow{2}{*}{ not found } & 20 & $>0.1$ & \multirow{2}{*}{ not found } & \multirow{2}{*}{$\begin{array}{l}\text { not } \\
\text { found }\end{array}$} & \multirow{2}{*}{$\begin{array}{l}\text { not } \\
\text { found }\end{array}$} \\
\hline after storage & 705 & & 22 & & & & \\
\hline $\begin{array}{l}0.2 \% \text { P-5-2 MCLN blend } \\
\text { for broilers for storage }\end{array}$ & 200 & \multirow{2}{*}{ not found } & \multirow{2}{*}{ not found } & $>0.1$ & \multirow{2}{*}{ not found } & \multirow{2}{*}{$\begin{array}{l}\text { not } \\
\text { found }\end{array}$} & \multirow{2}{*}{$\begin{array}{l}\text { not } \\
\text { found }\end{array}$} \\
\hline after storage & 200 & & & & & & \\
\hline \multirow[t]{2}{*}{ P 1 is granular } & 210 & 80 & \multirow{2}{*}{ not found } & $>0.1$ & \multirow{2}{*}{ not found } & \multirow{2}{*}{$\begin{array}{l}\text { not } \\
\text { found }\end{array}$} & \multirow{2}{*}{$\begin{array}{c}\text { not } \\
\text { found }\end{array}$} \\
\hline & 212 & 82 & & & & & \\
\hline \multirow[t]{2}{*}{ P 2 granular } & 240 & 60 & \multirow{2}{*}{ not found } & $>0.1$ & \multirow{2}{*}{ not found } & \multirow{2}{*}{$\begin{array}{l}\text { not } \\
\text { found }\end{array}$} & \multirow{2}{*}{$\begin{array}{c}\text { not } \\
\text { found }\end{array}$} \\
\hline & 240 & 60 & & & & & \\
\hline \multirow[t]{2}{*}{ P 3 briquetted } & 240 & 60 & \multirow{2}{*}{ not found } & $>0.1$ & \multirow{2}{*}{ not found } & \multirow{2}{*}{$\begin{array}{c}\text { not } \\
\text { found }\end{array}$} & \multirow{2}{*}{$\begin{array}{c}\text { not } \\
\text { found }\end{array}$} \\
\hline & 240 & 60 & & & & & \\
\hline$P$ is extruded & 305 & 55 & not found & $>0.1$ & not found & $\begin{array}{l}\text { not } \\
\text { found }\end{array}$ & $\begin{array}{c}\text { not } \\
\text { found }\end{array}$ \\
\hline
\end{tabular}

was studied storage efficiency of $1 \%$ and highly concentrated premixes produced in accordance with the developed technology of filler formation (Fig. 5).

Premixes made on the basis of $0.2 \%$ of aperture and different CFP (samples № 1, 2, 3) were put into storage. Wheat bran (sample No. 4), limestone flour (sample No. 5) and industrially manufactured $0.2 \%$ blend P-1-2 MKHLN for laying hens of an industrial herd of breed Hi-Line W-98 (sample No. 6) were selected as controls. 6). The samples were packed in 4-layer paper kraft bags and bags of polyethylene and stored for 40 days under unregulated conditions (at room temperature and unregulated humidity). The sanitary condition of the test specimens was evaluated before storage and during storage every 10 days. The results of the microbiota studies are given in table. 3.

Prior to storage, the microflora of the bran (sample 1) contained saprophytic microflora characteristic of wheat grain [9], which is represented by both sporeforming and non-spore-forming species (decaying bacteria - less than $1 \%$ and grass-stick - $4 \%$ of the total number of bacteria. Mold was found only in bran, morphologically related to the genus Mucor.

Pathogenic staphylococcus, bacteria of the genus Salmonella, Proteus and anaerobic microorganisms were not detected in the samples tested.

Within 40 days of storage, the total bacterial count of the bran remained virtually unchanged. Spore-forming bacteria were found only in limestone flour at $20 \mathrm{CFU} /$ g. Form and yeast circles were not detected in any specimen. Pathogenic Staphylococcus aureus and Salmonella were not detected in all premix samples.

The reduction of bacterial flora in all specimens of molded premixes is due to non-spore-forming microorganisms and vegetative forms of spore-forming ones, if any before storage, and due to heat treatment during granulation and extrusion.

With respect to the BGEC titer, all prototype premixes are considered to be safe because they did not exceed $0.1 \mathrm{~g}$ during the entire storage process. Pathogenic microorganisms were not sown after storage.

\section{Conclusions}

As a result of our research, we have improved the technology of preparation of complex filler by forming it in different ways depending on the composition. Such technological techniques in the preparation of CFP allow to obtain agglomerates of the filler with the specified size, eliminate the stratification and stabilize its composition during transportation and storage, which also further provides optimal conditions for its mixing with the preparations of BAA and to obtain a homogeneous premix. The premixes obtained by these technologies are more stable from the point of view of the sanitary condition, and it is also expedient to use them in the production of binary compound feeds and compound feeds of balanced granulometric composition.

\section{REFERENS}

Premixtures. Peter Fidder, Philippe Becquet, Cédric Martin, Mario Döpker, Juan José Mallo. Fefana, 2013. - 80 p.

Lebid' L. Premiksy: holovni faktory vyrobnytstva // 2014. - Ahrarnyy tyzhden', 2014. Serpen'. - S. 62-64.

Proyzvodstvo y yspol'zovanye premyksov / K. M. Solntsev [y dr.] ; pod red. K. M. Solntseva. -L.: Kolos. Lenynhr. otd-nye, 1980. - 288 s.

Tekhnolohiya vyrobnytstva premiksiv/ B.V.Yehorov, O.I.Shapovalenko, A.V.Makaryns'ka. Pidruchnyk. -K.: Tsentr uchbovoyi li-teratury,

2007. $-288 \mathrm{~s}$

5. Kishchak I.T. Vyrobnytstvo i zastosuvannya premiksiv. - Kyyiv: Urozhay, 1995. - 272 s.

Chernyshev N.Y., Panyn Y.H. Komponenty premyksov. 2-e yzdanye, 2012. $140 \mathrm{~s}$.

Ukrayins'kyy vyrobnyk kormiv yevropeys'koyi yakosti // Agroexper, 2016. - № 11 (100). - S. 56-57.

8. Traylor S. L., Hancock J.D., Behnke, Stark C. R., Hines R.H. Mix time effects diet uniformity and growth performance of nursery and finishing pigs. Swine Day Report, Kansas St. University, Manhattan. - 1994.

9. Problemy proizvodstva i ispol'zovaniya premiksov // Kombikorma. - 2000. - №2. - S.32-33. 
10. Kuznetsov S. G. Nauchnyye osnovy proizvodstva premiksov // Yefektivne ptakhivnitstvo ta tvarinnitstvo. - 2004. - №1. - S. 32-38.

11. Kozharova L. Osobennosti proizvodstva premiksov i BVD // Kombikorma. - 2000. - №3. - S. 20-21.

12. Yegorov B.V., Brazhenko V.Ye., Kovtun A.A. Sovershenstvovaniye tekhnologii podgotovki kompleksnykh napolniteley premi-ksov// Zernovi produkti i kombikormi, 2002. -№1. -S.45-47.

13. Petrov N. Puti sovershenstvovaniya tekhnologii prigotovleniya premiksov// Kombikorma. - № 6. - 2006. - S.47-49.

14. Yegorov B.V., Makarinskaya A.V., Brazhenko V.Ye. Tekhnologicheskiye osnovy proizvodstva premiksov novogo pokoleniya//II Mizhnarodna konferentsiya "Ukraïna. Kombikormi'2005”, 2005r. Zbirka dopovidey konferentsiï. - Saki, 2005. - S.30-33.

15. Kuznetsov S. G. Ot chego zavisit kachestvo premiksov // Kombikorma. - 2003. - №8. - S. 46-47.

16. Kuznetsov S., Frappa S. Mineral'nyye veshchestva i vitaminy dlya proizvodstva premiksov // Kombikorma, 2002. - №4. - S. 35-37.

17. Duncan M. S. Problems of dealing with raw ingredient variability// Recent Advances in Animal Nutrition, 1988. - P. 1-11.

18. Ehorov B.V., Makarynskaya A.V., Brazhenko V.E. Teoretycheskye y éksperymental'nye obosnovanyya proyzvodstva komplek-snykh napolnyteley. Naukovi pratsi ONAKHT/ MOiNU. - Odesa: 2002. - Vyp. 24: Nove v tekhnolohiyi zberihannya ta pererobky zerna. - S.175177.

19. D.p. Ukrayiny № 21485. MPK (2006) A 23K 1/16. Kompozytsiya inhrediyentiv kompleksnykh napovnyuvachiv pry vyrobnytstvi premiksiv/ Yehorov B.V., Makarynska A.V., Brazhenko V.YE. -№u 200610584; Zayavl. 06.10.2006; Opubl. 15.03.2007, Byul. № 3.

20. D.p. Ukrayiny № 21401. MPK (2006) A 23K 1/16. Sposib pidhotovky kompleksnykh napovnyuvachiv pry vyrobnytstvi premiksiv/Yehorov B.V., Makarynska A.V., Brazhenko V.YE. -№u 2006 10151; Zayavl. 22.09.2006; Opubl. 15.03.2007, Byul. № 3.

21. Ehorov B.V., Brazhenko V.E., Balochkyn V.Y. Tekhnolohycheskye osnovy povyshenyya éffektyvnosty napolnyteley premyk-sov// Zernovi produkty i kombikormy, 2002. -№2. -S.28-31.

22. Moloskyn S.A. Osobennosty tekhnolohyy proyzvodstva premyksov// Khranenye y pererabotka zerna. - 2000. - № 4. - S. 29-30.

23. Herasymov YA.V., Rysev O.A. Tekhnolohyya psevdokapsulyrovanyya - sovremennyy podkhod k proyzvodstvu premyksov// «Kombykorma». - 2008. - № 1 .

24. Pravyl'no vybraem premyks // Kombykorma, 2012. - № 6. - S. 90.

25. BASF v Pol'she // Kombykorma. - 2004. - №5. - S. 50-51.

26. Mashkivs'kyy M.M., Halyns'ka N.V. Stabil'nist' vitaminiv // The Ukrainian farmer, 2014. - May. - S. 121-124.

27. Gabrijela Tavyar-Kalcher, Anton Vengušt. Stability of vitamins in premixes // Animal Feed Science and Technology, 2007. - Vol. 132 (1). - P 148-154.

28. Gerald C. Shurson, et al. Effect of metal specific amino acid complexes and inorganic trace minerals on vitamin stability in premixes // Animal Feed Science and Technology, 2011. - Vol. 163 (2). - P. 200-206.

29. Michael c. Allwood, Melanie c. J. Kearney. Compatibility and Stability of Additives in Parenteral Nutrition Admixtures // Nutrition, 1998. - Vol. 14. - № 9. - P. 697-706.

30. Електронний ресурс. Режим доступу: http://sivetra-agro.ru/premix-catalog/absorbenty

31. Yegorov B.V., Makarynskaya A.V. Tekhnologicheskiye osnovy proizvodstva premiksov novogo pokoleniya. Naukovi pratsi Odes'k. nats. akad. kharch. tekhnologíy/ Ministerstvo osviti i nauki Ukraïni. - Odesa: 2007. - Vip. 30. - T. 2. - S. 72-76.

32. Pat. 2279812 RU. MPK S 2 A 23K/16 (2006.01) Sposob podgotovki otrubey, kak napolnitelya dlya premiksov/ A.A.Bugayev, I.N.Zhukova, Ye.V.Solov'yev i dr. Kubanskiy gos-nyy tekhnol. un-t. № 2004124287/13; zayavl. 09.08.2004; Opubl. 20.07.2006. - 4 s.

33. Makarynska A.V. Morskiye vodorosli kak komponent kombikormov// Zernoví produkti i kombikormi, 2014. - t. 14. - № 4 (56). - S.44-50.

34. Makarynska A.V. Tekhnologichni sposobi pererobki vodorostey // Zbirnik tez dopovídey 75 naukovoï konferentsiï vikladachiv akademiï. Odesa: MON Ukraïni, ONAKHT, 2015. - S. 28-29.

35. 35. Metodichni vkazivki do vikonannya laboratornikh robit z kursu "Tekhnologíya virobnitstva kormovikh zasobiv i kormovikh do-bavok" dlya bakalavriv spetsial'nosti 6.051701 dennoï i zaochnoï form navchannya / Ukladachí: A.V. Makarins'ka, N.V. Khoren-zhiy, T.V. Bordun I Za red. prof. B.V. Égorova. - Odesa: ONAKHT, 2015. - 55 s.

36. Slyusarenko T.P. Laboratornyy praktikum po mikrobiologii pishchevykh proizvodstv. - M.: Legkaya i pishchevaya prom., 1984. -246s.

37. Sanitarnaya mikrobiologiya/ Biletova N.V., Kornelayeva R.P., Kostrikina L.G. i dr. - M.: Pishchevaya promyshlennost', $1980 .-352$ s.

38. Petrov K.P. Praktikum po biokhimii pishchevogo rastitel'nogo syr'ya. - M.: Pishchevaya promyshlennost', 1965. -329s.

39. Yegorov B.V., Kuznetsov M.V. Fizicheskiye svoystva kombikorma v vide smesi krupok // Materialy konferentsii Tez. dokl. V Vsesoyuz. nauch. konf. "Mekhanika sypuchikh materialov", Odessa, 17 - 19 sent. 1991g. s. 40.

40. Patent № 1517908. Sposob polucheniya granulirovannogo kombikorma dlya sel'skokhozyaystvennykh zhivotnykh. B.V. Yegorov, V.V. Sherstobitov, V.V. Goncharenko, S.N. Kudashev, N.I. Grishchenko, V.T. Gulavskiy, M.V. Kuznetsov. № zayavki 4359544/30-15. Opubl. 1989.10.30.

41. Makarynska A.V., Yegorov B.V. Vid virobnitstva stabil'nikh preparativ biologíchno aktivnikh rechovin do virobnitstva sta-bil'nikh premiksiv (ch. 1) // Zernoví produkti i kombikormi, 2009. - t. 9. - № 4 (36). - S. 33-41.

\section{УДК [636.08452:636.087.7/8]:65.018}

А.В. МАКАРИНСЬКА, канд. техн. наук, доцент, кафедра технології комбікормів і біопалива Б.В. СГОРОВ, д-р техн. наук, професор, кафедра технології комбікормів і біопалива Одеська національна академія харчових технологій, м. Одеса (Україна)

\section{ТЕХНОЛОГIÏ ВИРОБНИЦТВА ФОРМОВАНИХ ПРЕМІКСІВ}

\section{Анотація}

В матеріалах статті представлено теоретичний аналіз та практичний досвід виробництва преміксів (П) за різними технологіями підготовки наповнювача. Вказані їх переваги та недоліки. Наведена класифікація напоінювачів преміксів для виробництва преміксів.

Теоретично та практично обтрунтовано технологію виробництва комплексного наповнювача преміксів (КНП) у формованому виді. Розглянуті різні способи формування в залежності від складу комплексного наповнювача, а також представлена технологічна схема їх виробництва.

Представлені результати промислової апробації технологій формування (гранулювання, брикетування, окатування, екструдування) наповнювачів та готових преміксів у виробничих умовах підприємства ТГ «ВБА» «Известняки». Досліджені фізичні показники формованих комплексних наповнювачів/преміксів, на основі аналізу отриманих даних встановлено, щуо гранулюванню та брикетуванню можна піддавати КНП, які складаються з $75 \ldots 50 \%$ висівок пшеничних та $25 \ldots 50 \%$ вапнякового борошна. Окатуванню - КНП, який складається 3 85 \% висівок пшеничних та $15 \%$ вапнякової муки. Встановлено оптимальні технологічні режими формування КНП та П різними способами, в результаті яких можна одержувати частинки П, які при подальшому змішуванні з компонентами комбікорму забезпечують високу однорідність готового комбікорму. 
Наведені результати вивчення мікробіологічних показників, встановлено, що формування КНП або П зменшує бактеріальну флору та покращує умови при їх зберіганні.

Запропоновані технологічні прийоми підготовки КНП дозволяють усунути розшарування та стабілізувати його склад під час транспортування та зберігання.. Отримані за даними технологіями П є більш стабільними, їх доцільно застосовувати при виробництві бінарних комбікормів та комбікормів вирівняного гранулометричного складу.

Ключові слова: премікс (П), наповнювач, комплексний наповнювач (КНП), гранула, окатиш, екструдат, крупка, технологія гранулювання, технологічні режими, однорідність, фізичні властивості, мікробіологічні показники.

\section{ЛІТЕРАТУР}

1. $\quad$ Premixtures. Peter Fidder, Philippe Becquet, Cédric Martin, Mario Döpker, Juan José Mallo. Fefana, 2013. - 80 p.

2. Лебідь Л. Премікси: головні фактори виробництва // 2014. - Аграрний тиждень, 2014. Серпень. - С. 62-64.

3. Производство и использование премиксов/ К.М. Солнцев [и др.]; -Л : Колос. Ленингр. отд-ние, $1980 .-288$ с.

4. Технологія виробництва преміксів/ Б.В.Сгоров, О.І.Шаповаленко, А.В.Макаринська. Підручник. -К.: Центр учбової літератури, 2007. $-288 c$

5. імак I.T. Виробниитво і застосування преміксів. - Киӥв: Урожсай, 1995. - 272 с

6. Чернышев Н.И., Панин И.Г. Компоненты премиксов. 2-е издание, 2012. 140 с.

7. Украӥнський виробник кормів європейської якості // Agroexper, 2016. - № 11 (100). - C. 56-57.

8. Traylor S. L., Hancock J.D., Behnke, Stark C. R., Hines R.H. Mix time effects diet uniformity and growth performance of nursery and finishing pigs. Swine Day Report, Kansas St. University, Manhattan. - 1994.

9. Проблемы производства и использования премиксов // Комбикорма. - 2000. - №2. - С.32-33

10. Кузнецов С.Г. Научные основы производства премиксов // Ефективне птахівництво та тваринництво. - 2004. - №1. - С. 32-38

11. Кожарова Л. Особенности производства премиксов и БВД // Комбикорма. - 2000. - №3. - С. 20-21.

12. Егоров Б.В., Браженко В.Е., Ковтун А.А. Совершенствование технологии подготовки комплексных наполнителей премиксов// Зернові продукти і комбікорми, 2002. -№1. -С.45-47.

13. Петров Н. Пути совериенствования технологии приготовления премиксов// Комбикорма. - № 6. - 2006. - С.47-49.

14. Егоров Б.В., Макаринская А.В., Браженко В.Е. Технологические основы производства премиксов нового поколения//II Міжнародна конференція “Україна. Комбікорми'2005”, 2005р. Збірка доповідей конференції. - Саки, 2005. - C.30-33.

15. Кузнецов С.Г. От чего зависит качество премиксов // Комбикорма. - 2003. - №8. - С. $46-47$

16. Кузнецов С., Фраппа С. Минеральные вещества и витамины для производства премиксов // Комбикорма, 2002. - №4. - С. 35-37.

17. Duncan M. S. Problems of dealing with raw ingredient variability// Recent Advances in Animal Nutrition, 1988. - P. 1-11.

18. Егоров Б.В., Макаринская А.В., Браженко В.Е. Теоретические и экспериментальные обоснования производства комплексных наполнителей. Наукові праці ОНАХТ/МОіНУ. -Одеса: 2002. -Вип.24: Нове в технологї̈ зберігання та переробки зерна. - С.175-177.

19. Д.п. України № 21485. МПК (2006) А 23К 1/16. Композиџія інгредієнтів комплексних наповнювачів при виробництві преміксів/ Єгоров Б.В., Макаринська А.В., Браженко В.С. - №u 2006 10584; Заявл. 06.10.2006; Опубл. 15.03.2007, Бюл. № 3.

20. Д.п. України № 21401. МПК (2006) А 23 1/16. Спосіб підготовки комплексних наповнювачів при виробництві преміксів/ Єгоров Б.В., Макаринська А.В., Браженко В.С. -№u 2006 10151; Заявл. 22.09.2006; Опубл. 15.03.2007, Бюл. № 3.

21. Егоров Б.В., Браженко В.Е., Балочкин В.И. Технологические основы повышения эффективности наполнителей премиксов// Зернові продукти і комбікорми, 2002. -№2. -С.28-31.

22. Молоскин С.А. Особенности технологии производства премиксов// Хранение и переработка зерна. - 2000.-№ 4. -С.29-30.

23. Герасимов Я.В., Рысев О.А. Технология псевдокапсулирования - современный подход к производству премиксов// «Комбикорма». - 2008. - № 1 .

24. Правильно выбраем премикс // Комбикорма, 2012. - № 6. - С. 90.

25. ВАSF в Польше // Комбикорма. - 2004. - №5. - С. 50-51.

26. Машківський М.М., Галинська Н.В. Стабільність вітамінів // The Ukrainian farmer, 2014. - Maй. - C. 121-124.

27. Gabrijela Tavyar-Kalcher, Anton Vengušt. Stability of vitamins in premixes // Animal Feed Science and Technology, 2007. - Vol. 132 (1). $-P$ 148-154.

28. Gerald C. Shurson, et al. Effect of metal specific amino acid complexes and inorganic trace minerals on vitamin stability in premixes // Animal Feed Science and Technology, 2011. - Vol. 163 (2). - P. 200-206.

29. Michael c. Allwood, Melanie c. J. Kearney. Compatibility and Stability of Additives in Parenteral Nutrition Admixtures // Nutrition, 1998. - Vol. 14. - № 9. - P. 697-706.

30. Електронний ресурс. Режим доступу: http://sivetra-agro.ru/premix-catalog/absorbenty

31. Егоров Б.В., Макаринская А.В. Технологические основы производства премиксов нового поколения. Наукові праці Одеськ. наи. акад. харч. технологій/ Міністерство освіти і науки Украӥни. - Одеса: 2007. - Вип. 30. - T. 2. - С. 72-76.

32. Пат. 2279812 RU. МПК C 2 А 23K/16 (2006.01) Способ подготовки отрубей, как наполнителя для премиксов/ А.А.Бугаев, И.Н.Жукова, Е.В.Соловьев. Кубанский гос-ный технол. ун-т. № 2004124287/13; заявл. 09.08.2004; Опубл. 20.07.2006. - 4 c.

33. Макаринская А.В. Морские водоросли как компонент комбикормов // Зернові продукти і комбікорми, 2014. - т. 14 . - № 4 (56). C. $44-50$.

34. Макаринська А.В. Технологічні способи переробки водоростей // Збірник тез доповідей 75 наукової конференцї викладачів академії. Одеса: МОН України, ОНАХТ, 2015. - С. 28-29.

35. Методичні вказівки до виконання лабораторних робіт з курсу “Технологія виробничтва кормових засобів $і$ кормових добавок” для бакалаврів спеціальності 6.051701 денної і заочної форм навчання / Укладачі: А.В. Макаринська, Н.В. Хоренжсий, Т.В. Бордун / За ред. проф. Б.В. Сгорова. - Одеса: ОНАХТ, 2015. - 55 c.

36. Слюсаренко Т.П. Лабораторный практикум по микробиологии пищевых производств-М.:Легкая и пищ.пром., 1984.-246с.

37. Санитарная микробиология/ Билетова Н.В.,Корнелаева Р.П., Кострикина Л.Г. и др. -М.: Пищевая промышленность, 1980. -352 с.

38. Петров К.П. Практикум по биохимии пищевого растительного сырья. - М.: Пищевая промышленность, $1965 .-329$ с.

39. Егоров Б.В., Кузнецов М.В. Физические свойства комбикорма в виде смеси крупок // Материаль конференции Тез. докл. V Всесоюз. науч. конф. “Механика сыпучих материалов”, Одесса, 17 - 19 сент. 19912. с. 40.

40. Патент № 1517908. Способ получения гранулированного комбикорма для сельскохозяйственных животных. Б.В. Егоров, В.В. Шерстобитов, В.В. Гончаренко, С.Н. Кудашев, Н.И. Грищенко, В.Т. Гулавский, М.В. Кузнецов. № заявки 4359544/30-15. Опубл. 1989.10.30.

41. Макаринская А.В., Егоров Б.В. Від виробництва стабільних препаратів біологічно активних речовин до виробництва стабільних преміксів (ч. 1) // Зернові продукти і комбікорми, 2009. - т. 9. - № 4 (36). - С. 33-41.

Надійила 14.03.2019. До друку 05.01.2019. Рецензія 05.04.2019 Адреса для переписки: 65039, Odessa, str. Kanatnaya 104, r. А 224. 